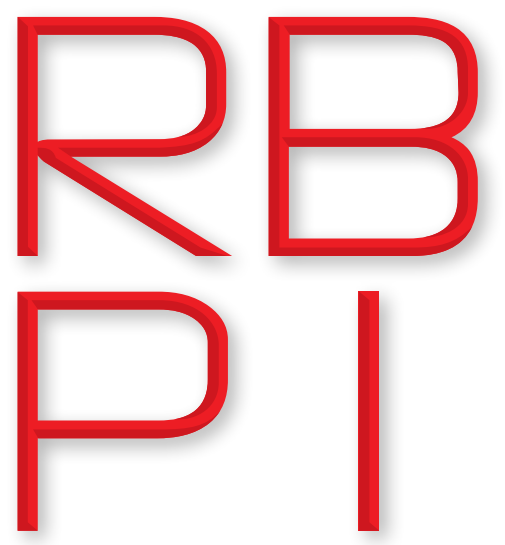

Revista Brasileira de Política Internacional ISSN 1983-3121

http://www.scielo.br/rbpi

\section{Patrick O. Cohrs}

University of Florence. History Department, Florence, Italy. (patrick.cohrs@unifi.it).

\section{Copyright:}

- This is an open-access article distributed under the terms of a Creative Commons Attribution License, which permits unrestricted use, distribution, and reproduction in any medium, provided that the original author and source are credited.

- Este é um artigo publicado em acesso aberto e distribuído sob os termos da Licença de Atribuição Creative Commons, que permite uso irrestrito, distribuição e reprodução em qualquer meio, desde que o autor e a fonte originais sejam creditados.

\section{"Pax Americana": the United States and the transformation of the $20^{\text {th }}$ century's global order}

DOI: https://dx.doi.org/10.1590/0034-7329201800202

\section{Abstract}

This article seeks to re-appraise the transformation of America's international role and its influence on the transformation of the $20^{\text {th }}$ century's global order. It focuses on a re-appraisal of US aspirations to construct a "Pax Americana" and their impact on an unprecedented peace system that was first conceptualised after 1918 but only consolidated after 1945: the cold war's transatlantic peace order. Yet my analysis also highlights important distinctions between American conceptions and behaviour vis-à-vis Europe and the superpower's more hierarchical and often neo-imperialist approaches to "global order" and other regions during the cold war, including East Asia and Latin America.

Keywords: Pax Americana; global order; 20 th -century international history; transatlantic peace system.

Received: April 26, 2018 Accepted: July 23, 2018

\title{
"Pax Americana"
}

I $\mathrm{t}$ is hard to overstate how profoundly the international role of the United States changed during the "short" $20^{\text {th }}$ century, which began with the "original catastrophe" of World War I. Before the watershed of the Great War, the American Republic had essentially been an imperialist power that eschewed wider international commitments; in its aftermath, it would ascend to the position of a superpower whose elites sought to recast the global system along American lines. In a wider historical context, it was between 1914 and 1991 that not only America's unprecedented power but also distinctive US conceptions and policies arguably came to have a dominant, though in many ways ambivalent, influence on the transformation of the international order. More precisely, they eventually shaped a drawn-out and conflict-ridden transformation 
process. This can best be described as a process marked by successive efforts - undertaken by American policy - and decision-makers in cooperation and consultation with their counterparts in other countries, notably in (Western) Europe - to replace the imperialist and still Eurocentric "world order" of the $19^{\text {th }}$ century with a more sustainable, modern and legitimate global order for the $20^{\text {th }}$ century.

To shed new light on these transformation processes, this essay focuses on a reappraisal of US aspirations for a "Pax Americana" and their impact on the emergence of an unprecedented system of peace and international politics whose first contours emerged after 1918, but which would only be consolidated after 1945: the 20 th century's transatlantic peace order. Essentially, these aspirations will be interpreted as a series of attempts - made by principal American and non-American policymakers, yet also unofficial actors who influenced international politics - to draw lessons from two world wars and the frustration of previous attempts to create a "new world order," above all the failure of Woodrow Wilson's quest to make the world "safe for democracy." Trying to build on such lessons, not only American protagonists but also key European and other non-American actors eventually came to advance more comprehensive designs and pursued more comprehensive "reordering" strategies. Above all, these actors came to play leading parts in transnational efforts to construct a qualitatively new international system - a system of collective security and shared political, economic and "civilisational" premises in which the ever more predominant power essentially came to assume the role of a liberal hegemon or primus inter pares, rather than that of an "American empire."

Yet, my analysis also focuses on the transatlantic sphere, in order to highlight important distinctions between American conceptions and behaviour vis-à-vis (Western) Europe, and the superpower's distinctly more hierarchical, and often neo-imperialist, approaches both to "order" on a global scale and to other regions of the world, notably in the era of the global Cold War. In critical respects, such approaches marked US hegemonic behaviour in East Asia. They prevailed in relations with Latin America. And they came to characterise US ambitions to extend an "American peace" to the "Third World," especially in the critical decade of the 1960s. All of this had consequences that are still palpable in the $21^{\text {st }}$ century.

\section{Towards a new interpretation of the "Pax Americana"}

Recent debates in international history and international relations have centred on the nature and extent of American predominance in the $20^{\text {th }}$ century. Scholars - e.g., Hunt (2007); Maier (2006); Ikenberry (2011); or Schroeder (2004) - have focused on the question of how far what emerged should be called a new "American empire," or rather a distinctive form of hegemony. They have attempted to assess what distinguishes the American case from previous imperial "systems of order," particularly the British "world order" of the $19^{\text {th }}$ century. In the context of these debates, the term "Pax Americana" is still most commonly used to describe the American 
superpower's supremacy after 1945, mainly in the "Western world," and the relative peace, stability, and prosperity it brought to some, but by no means all states and societies that came to be in the US sphere of influence during the Cold War. At the same time, there has been an ever more dominant tendency to link different notions of an "American peace" with the rise of a new kind of American empire, eventually a "Cold War empire." From different angles, it has been asserted that the Cold War saw both the unprecedented expansion of a US "empire of production" and of an American "empire by invitation," above all in Western Europe. Different interpretations of this kind have been advanced by Gaddis (1997), Maier (2006), Lundestad (1990), Westad (2005), Thompson (2015), and O'Brien and Clesse (2002).

The following analysis seeks to advance a different interpretation of what it appraises as the United States' novel hegemonic role in advancing one fundamental transformation process in the aftermath of World War II: the making and consolidation, not of a neo-imperial "Pax Americana," or "empire by invitation," but of a distinctive transatlantic peace order, which became a crucial, yet also exceptional element, or building block, of the global international system that was configured in the second half of the $20^{\text {th }}$ century. This order crystallised around the nucleus of a novel Atlantic community, which can also be interpreted as a distinctive Atlantic international society. It came to comprise the United States and the states of Western Europe, including West Germany; it was underpinned by a new kind of American hegemony. It came to be constructed through processes of transnational exchange and consultation, the forging of essentially cooperative, mutually authorised and acceptable designs of order and the willingness of key protagonists on both sides of the Atlantic to engage in complex negotiations to this end and to balance different political, economic, cultural and particularly security concerns and needs - in a period when the United States became the ever more clearly predominant power. What came to be pursued was a common bid that eventually clearly transcended "zero-sum Realpolitik," and led to the formation of a novel transatlantic system of order that was premised not only on a mutually beneficial intertwining of political priorities and interests, but also on a more than merely ideological foundation of common rules, principles and values.

The Euro-Atlantic system that emerged after 1947, as the result of more long-term processes that began in earnest in 1917, was based on an unprecedented architecture of international agreements and transnational networks, notably the European Recovery Program, the North-Atlantic Alliance and the broader system of understandings and cooperative links that emerged through and around them. Overall, it proved remarkably durable and legitimate. For the American and European actors who conceptualised it, this system was to become a nucleus for a global order and set an example for the world. It should be understood as a primarily Euro-Atlantic rather than a more universal, let alone a global, phenomenon. This is because US aspirations to extend a "Pax Americana" outside the transatlantic sphere often turned into actual neo-imperial endeavours or gave rise to systems of order that had neo-imperial characteristics and in fundamental respects lacked legitimacy. Noteworthy historical and theoretical works that have analysed the United States' hegemony in the $20^{\text {th }}$ century's international system include Ikenberry (2006), Clark (2011), Menzel (2015), Iriye and Osterhammel (2014), and Cox, Dunne and Booth (2001). 
Recent contributions have also rightly stressed that American decision-makers never merely developed their conceptions of foreign policy and international order all on their own, removed from foreign influences. Nor, at least concerning Europe, did they essentially impose "Americanist" visions on other, less powerful states and societies. Rather, they adopted and adapted ideas and concepts from others, notably different European blueprints. This applied to modern welfare-state conceptions in the context of Franklin Roosevelt's national, and later global, New Deal reform agenda of the 1930s and 1940s or later - and crucially - to the core idea of constructing a transnational system of collective security through the North Atlantic alliance (Patel 2016) and Trachtenberg (1999). In this respect, British and French Atlanticists had a decisive impact. They in turn built on blueprints for a transatlantic security system that had first been advanced thirty years earlier, during the First World War and the Paris Peace Conference of 1919, particularly by the French strategist André Tardieu, as has been shown by Jackson (2013) and Cohrs (unpublished). Yet, it is highly characteristic of US strategies and approaches in the "American 20th Century" that both in the case of the New Deal and then of North Atlantic Treaty Organization (NATO), such conceptions were ultimately "Americanised" and presented - especially in the United States, yet also to the world - as outgrowth of a new, distinctly American vision for a more advanced and secure international system and model of a more progressive and effective welfare state.

\section{Learning processes and the underpinnings of the Atlantic peace after World War II}

However, neither the nature of American hegemony nor the distinctiveness of the novel transatlantic peace system that emerged after 1945 can be simply explained as a consequence of the eventual US preponderance of power in military, economic and technological terms, the attractiveness of the American "model of the future," or the competition with rival ideologies and systems, from authoritarian and fascist to communist alternatives. What had a more profound impact can be characterised as a salient reorientation process - and, in many ways, a long-term learning process, which led to a significant evolution of the ideas and assumptions that informed American approaches to the practice and legitimation of modern international politics. In turn, as should be emphasised again, these approaches, as well as the ideas and conceptions underlying them, were developed consciously at times. However, they were often also unconscious processes of exchange and learning, of adaptation and adoption, in which US strategists and political decision-makers engaged - from an increasingly superior position - with key policymakers from abroad, but also from other national and transnational backgrounds.

However, it remained crucial for most American "architects" of the international order after 1917 that they ultimately developed and publicly presented essentially Americanist conceptions and policies - conceptions and policies to reform, stabilise and pacify Europe and the rest of the world along "exemplary" American lines. This was not only due to their self-image and their 
higher mission. It was also a reaction to one cardinal necessity they faced, namely to ensure the domestic legitimacy of and public support for the new hegemonic role and far-reaching responsibilities they thought the American power had to assume in the face of unprecedented global challenges. No less important was the challenge to legitimise America's new "benevolent" hegemony internationally or, more precisely, in societies that now had to come to terms with the new critical American preponderance and increasingly pervasive political, economic, social and cultural influence. In short, while there was the temptation to act unilaterally and impose a "Pax Americana" - which ultimately could not be resisted - in America's relations to other parts of the world, what prevailed in its relation to Europe, after 1945, was the overall commitment to create and preserve a new consensual, and ultimately far more legitimate, thus durable "Pax Atlantica."

In a broader context, the making of the $20^{\text {th }}$ century's transatlantic peace order can be seen as the result of the most conscious and far-reaching attempts to learn from the shortcomings and ultimate failure of previous American and international endeavours to recast and reform international order in the aftermath of the Great War. Above all, consequences were drawn from the peacemaking efforts of 1919 and Wilson's frustrated bid to create a "new world order" on American terms, premised above all on the creation of a League of Nations and the spread of American-style self-government. Yet, consequences were also drawn from the attempts of Republican governments, private financiers and non-governmental networks, such as the movement to "outlaw war," to modernise international relations and consolidate a new order according to "the American way," during the interwar period. The World Economic Crisis undermined these attempts. Distinctly different interpretations of these processes have been advanced by Cohrs (2006) and Tooze (2015).

Long-term and ultimately transformative changes in underlying conceptions and assumptions, individual and collective outlooks, and learning processes of this kind proved critical for transforming America's role in building and maintaining durable systems of international security, politics, and economics after 1945. They were instrumental for the development of American peace designs for "One World" under Roosevelt, generally based on the Atlantic Charter of 1941 and subsequent conceptions for a global order anchored in the United Nations. They also informed the aspirations for a different kind of Atlantic order that the Truman administration and the official and nongovernmental American protagonists of the late 1940s and early 1950s came to pursue. Then, not merely the pressures of the intensifying Cold War, but also more profound reorientations had a significant influence on US engagement on behalf of (West) European reconstruction through the Marshall Plan. At the same time, they buttressed US encouragement of European efforts to achieve supranational integration - and, tightly bound up with this, the international (re)integration of what became Western Germany. Finally, and crucially, they also had a formative effect on how the US decision-makers made - and legitimised - unprecedented peacetime commitments to collective security through the new Atlantic Alliance. New historical and theoretical perspectives on the relevance of learning processes and the use of history and historical analogies in US foreign policy have been opened up by Jervis (1976), May (1973), Khong (1992), and Cohrs (2006). 


\section{Distinctions: The Transatlantic order and the global context}

When reappraising developments in the post-World War II era, what can be thrown into relief is a significant shift: the departure from the original focus on a "global" conception of order under the Roosevelt administration - and from its leadership in inter - and transnational efforts - to found such a new global order, whose superstructure was to be provided by the United Nations and the institutions of the Bretton Woods system. While Roosevelt's successors also adopted global outlooks and long-term conceptions, they would concentrate on laying the groundwork for what can be described as a complex of partly interconnected, yet in many respects separate and distinct "regional peace systems" under American auspices: above all, the novel transatlantic order, but also the system of bilateral alliances and modernisation in East Asia, as well as the US-dominated "Cold War" system of the Western hemisphere. These systems, forged under the impact of the escalating Cold War - to which the policies of the Truman administration contributed significantly - represented different forms of a "Pax Americana." Within them, the United States always played the leading role, though it did so in qualitative gradations from that of a comparatively benign hegemon to that of a new kind of empire.

In the context of the Cold War's systemic competition with the Soviet Union and "polycentric" communism, American ambitions eventually came to reach further. The instrumentalities and blessings of an "American peace" were to be extended in a global setting - concretely: what became known as the "Third World" in the era of decolonisation. However, such aspirations were often frustrated and tended to generate disorder, rather than anything approaching legitimate order. This will be illustrated by a brief appraisal of the Johnson administration's conception of a global New Deal, and its pursuit of a Marshall Plan for Southeast Asia, which would be undermined by the escalation of the war in Vietnam.

\section{Novel qualities? The unprecedented scope of "Pax Americana" aspirations}

What, then, were the salient characteristics of designs for an "American peace" in the $20^{\text {th }}$ century? What made them distinctive, and so influential - both positively and negatively - in what became, inter alia, an "American century?" A central thesis in this essay is that, ever since the Wilson era, the novel quality of US aspirations not only to reform but to transform the international system derived from their potentially universal scope and from the comprehensive nature of their conceptions of peace and political and economic order that informed them. In turn, these conceptions were informed by distinctive Americanist ideologies. In their most ambitious manifestations, they were based on the premise that durable peace required more than a system of treaties and diplomatic understandings between governments and states: it depended on fundamental changes of the rules, norms and institutional underpinnings in both international and inner-state orders. This went hand in hand with the fundamentally progressive assumption 
that the exemplary American power could not only offer such peace-enforcing rules and norms, but was also called upon to play a leading role in international efforts to transform world "and" domestic politics - two spheres that became ever more intricately intertwined in what also became a century of transnational interconnectedness and interdependence.

In the international sphere, American aspirations came to centre on the establishment of global and then more specifically regional institutions of collective security and the peaceful disputes' settlement - from the League of Nations to the United Nations, and subsequently, the North Atlantic Alliance. They came to concentrate an institutional framework for a liberal world economic order - from the "open door" system in the World War I era to the institutions of the Bretton Woods system and, subsequently, the European Recovery Program. These were always closely linked with the notion of the salutary and peace-enforcing effect of a broader transformation process: ultimately the globalisation of American principles and rules of democratic self-government, and statehood, as well as a liberal mode of capitalism and both cultural and social norms that the United States exemplified.

A more extensive "Americanisation" process affecting other states and societies began to affect in the aftermath of World War I, notably in Europe, but it gained real momentum after 1945. In a wider context, and in the long run, what proved immensely consequential was the American impact on the process of "globalisation" in the late $20^{\text {th }}$ century (the "second wave," after that of the final period of the "long" $19^{\text {th }}$ century) - the intensification of global interconnectedness in the political and economic spheres and the transnational circulation not just of capital and political practices, but also of cultural precepts and ideas of social organisation. This process had a long pre-history and was initially constrained by the Cold-War division of the world in competing blocs; however, it acquired new dynamism from the late 1960s.

Essentially, ever since Wilson had first formulated this aspiration, playing a leading part in building a "new world order" required US decision-makers, and those who influenced US international policies, to transcend legacies of American isolationism, aloof exceptionalism, yet also formal and informal imperialism. It required them to break with long-standing American traditions of acting unilaterally and eschewing wider international responsibilities. It also required them to re-evaluate the principles and practices of democratic government and liberal capitalism that the United States was supposed to exemplify. That had been challenged to an unprecedented degree since 1914: by two world wars and one Great Depression, by the alternative ideological designs of National Socialism, the Japanese bid for a "Co-Prosperity Sphere" - and eventually not only by Stalin's Empire, but also by communist modernisation schemes for Europe and the "Third World."

After 1945, as after 1918, the critical challenge for official US policymakers was to learn how to develop multilateral, cooperative and historically informed peace designs. At the same time, they had to learn how to exercise and legitimise a liberal American hegemony, and how to work and consult with others in the international "order" they aspired to create. Much the same applied to the ever-expanding spectrum of individuals, non-governmental associations, and foundations - such as the Carnegie Endowment for Peace, and later the Ford Foundation - that aimed to 
promote an "American peace" through increasingly more complex transnational networks. Put differently, what tended to mar US aspirations was a proclivity towards an imperial-paternalist and eventually also technocratic unilateralism that often led US policymakers, experts, and activists to act as neo-imperial modernisers. As the theologian Reinhold Niebuhr put it in the early 1950s, overzealous "tutors of mankind in its pilgrimage to perfection" (Niebuhr 2008, 71, 74-5). During the Cold War, this tendency was criticised both by avowed "realists," such as George Kennan, and internationalists, such as William Fulbright (Kennan 1954; Fulbright 1966). The roots of such tendency reach back much further: not only to Wilsonian Progressivism during World War I but also to American progressive imperialism in the Western Hemisphere and the Philippines during the late $19^{\text {th }}$ and early $20^{\text {th }}$ centuries. Though bringing about some qualitative and some merely rhetorical changes, the Great War did not mark the beginning of Americanist conceptions of order along these lines. It only accelerated aspirations to apply them to the world as a whole. In the World War II era, this would be attempted on a significantly grander scale.

\section{The Roosevelt Era - Aspirations to globalise an "American Peace?"}

Franklin Roosevelt has often been accused of bequeathing a burdensome legacy to those who had to direct America's international policies after his death, mainly because of his allegedly illusory aspiration to build a post-war system that was based on cooperative relations with the Soviet Union. In retrospect, however, Roosevelt's quest for an "American peace" for "One World" can be interpreted in a different light. In critical respects, it had a formative and lasting impact on the United States' role in the world after World War II. Roosevelt and US post-war planners in the 1940s sought to draw more profound consequences from two World Wars and a disastrous Great Depression. Building on some of Wilson's core "Americanist internationalist" premises, yet also seeking to develop more realistic strategies, Roosevelt came to develop the conception of a universalist and ultimately integrative international order in which the United States was to play a pivotal hegemonic role. This order was to be based on the Four Freedoms and the Atlantic Charter of 1941, although the latter furnished only very vague and general maxims.

Though reluctant at first, Roosevelt also came to make the United States the key power behind efforts to establish a more authoritative international organisation than the League of Nations had been allowed to become: the United Nations. Roosevelt also envisaged that the United States and the other principal victors of the war - above all, the Soviet Union, Britain and, in his vision, China - would have special hegemonic responsibilities and prerogatives within the new United Nations (UN) system: they were to form a directorate of the post-war world. In his judgement, the "Four Policemen" were indispensable not only to prevent the Axis powers from ever challenging peace again but also to oversee global pacification processes in the unsettled post-war period.

Roosevelt, as well as those who recast American approaches to international and domestic politics under his presidency, thus fostered a highly significant transformation process: the United States, 
which had been a potential hegemon before 1941, acquired the political, strategic and economic wherewithal to emerge as the pre-eminent superpower after the Second World War. Roosevelt himself played a crucial role in redefining the United States' global responsibilities. It would make lasting international commitments as an essentially liberal hegemonic power and play a key role in forging and maintaining new international institutions and global ground-rules after the war. Like Wilson, Roosevelt and his main advisers deemed it crucial to avoid a re-emergence of rigid spheres of influence that were controlled by rival great powers. In the president's view, outlined in his Annual Message to Congress of 6 January 1941, it was imperative to base the post-war international order "upon a world-wide conception" (Rosenman 1947). This, in turn, required the establishment of more effective global institutions and mechanisms to regulate the affairs of an ever more interconnected and interdependent world. This logic lay behind the Roosevelt administration's ultimately decisive support for the creation of the United Nations as a more effective institution to "superintend" global order - a course it had been pressed to take by an increasingly influential pro-United Nations movement in the United States. The same logic informed the key American contributions to constitute the Bretton Woods system, which was to create a novel framework for post-war financial and economic order. Therefore, the Roosevelt administration sought to foster the globalisation of the "ordered" US liberal capitalism of the latter 1930s and early 1940s. In a wider context, it intended to launch a "New Deal for the World" (Borgwardt 2005; Cohrs 2009).

Revived and reformed American internationalism of this kind provided the critical impetus to the establishment of the United Nations. The Atlantic Charter also became a template for the UN Charter and its novel emphasis on protecting human rights - the rights of individuals. While the Roosevelt administration reasserted the Wilsonian maxim of "self-government" - the right of all peoples to choose freely the form of government under which they desired to live - it refrained from making "self-determination" an explicit core principle of the new world order it pursued. More unequivocally than after World War I, it was meant to be an order whose terms were to be set by the victors, after an unconditional surrender of the Axis powers, and influenced by their conceptions and overriding interests.

On a broader perspective, Roosevelt's "One World" was formative in another respect. He based his vision of an integrative "Pax Americana," and of a cooperative engagement of the Soviet Union, on one fundamental premise. It was the premise that the more US policy could open up avenues for integrating all states and societies - including the vanquished powers, following their "unconditional surrender" - into an "open" - liberal - international system, the more powers, even those that, such as the Soviet Union, espoused a diametrically opposite ideology, would, over time, gravitate to what he deemed the inherently more attractive US model. Fundamental for Roosevelt's ideas about post-war order was his confidence that, after the experiences of the 1930 s and the war effort, that American principles of liberal yet regulated political order and capitalism would eventually supersede communist ideology and, in this sense, foster a global process of "Americanisation." The Roosevelt administration's aspirations can thus be characterised as the first concerted attempt to internationalise an American-style New Deal. 


\section{The making of the novel Atlantic Peace Order after World War II}

Arguably the most important bid for a "Pax Americana" in the $20^{\text {th }}$ century was the one advanced by the Truman administration, which was significantly conditioned by the escalating confrontation with the Soviet Union. Containing the spread of Soviet influence in every sphere - from the heights of superpower relations to the level of local politics, economics, and culture - became the central US mission, whose long-term aim remained to overcome the Soviet system and globalise an "American peace." The transformation of US post-war policy under Truman had contributed to the deepening of a US-Soviet antagonism fuelled by mutual misperceptions. The Truman administration's new course also fostered something different: significant qualitative changes in America's role within the international system - and, above all, the founding of an unprecedented transatlantic international order.

This order, whose foundations were laid between 1947 and 1955, can be characterised, not so much as a Euro-Atlantic "Pax Americana," but as an integrative, cooperative and mutually legitimate Atlantic peace. It would thus be misleading to characterise it - as Lundestad (2003) has done - as a peace system whose parameters were set, dominated by a new kind of "American empire" or even "empire by invitation." Instead, the reorientation of US hegemonic policies, and the fundamental learning processes that informed it propelled advances towards an ultimately cooperative order, rather than an imposed, mutually authorised, mutually accepted and progressively integrated transatlantic system of security, economic reform, and revitalisation. What emerged was thus a hegemonic but cooperative Pax Atlantica, not a unilaterally imposed, neo-imperial "Pax Americana," such as that which had come to prevail in the United States' relations with Latin America and other parts of the Cold War world. This distinctive and novel peace system was essentially founded through the European Recovery Program and the North Atlantic Alliance - that came to incorporate the states of Western Europe and West Germany. By comparison, as will be shown, America's role in relations with Japan and East Asia after 1945 was also, overall, that of a comparatively benign hegemon, rather than that of a novel kind of empire. However, US predominance and hierarchical high-handedness were undoubtedly more pronounced here.

Ultimately, what led American and European policymakers - as well as non-governmental experts - to develop new approaches and espouse distinctly more far-reaching aims and firmer transatlantic commitments in the late 1940s were not just the pressures caused by the escalating Cold War with the Soviet Union. On a deeper level, what mattered most - more than has been hitherto recognised - were long-term changes in outlook and mentality on both sides of the Atlantic -, as well as long-term learning processes. These pivoted on the realisation that consequences had to be drawn from the problems and perceived failure of peacemaking in 1919. On one level, Roosevelt's successors sought to avoid a new post-war conflict over reparations, which had had a very destabilising impact on Europe after 1918. They drew consequences from the perceived failure to address the problem of inter-allied war debts - and from the essentially non-governmental US pursuits of European stabilisation after World War I, which the Republican administrations of the 1920s had 
largely left in the hands of "private" US experts and financiers, and which had collapsed - with grave consequences - under the impact of the World Economic Crisis. On these premises, they made unprecedented commitments to a government-led, transnationally-organised approach to post-war reconstruction, especially through the Marshall Plan - which, originally conceived in broader, potentially global terms, would come to centre on Western Europe and West Germany.

Perhaps even more significantly, they sought to learn from what they saw as the problems inherent to Wilson's championing of the League and his failure to legitimise his call for new global responsibilities, particularly under the League's "collective security" regime, in the court of the American Senate, and of public opinion.

In this endeavour, they would seize on key impulses by and effectively join forces with leading European "architects of order," such as Jean Monnet, Ernest Bevin and later Konrad Adenauer. Although, from different vantage-points, they were motivated by the goal to ensure that, unlike the 1920s, the American power would not "withdraw" from political and wider economic responsibilities in Europe. Building on the concepts Tardieu and others had advanced since 1917, they all developed strategies whose underlying goal was to integrate the American superpower into a new and more sustainable architecture of security, political reform, and economic reconstruction and development. Furthermore, they also deemed American support essential to open up a realistic path towards supranational integration in (Western) Europe. Eventually, Adenauer and the democratic representatives of the new Western-orientated German Federal Republic would also be involved and play a significant role in this process. The key objective all of these actors shared, as well as with their American counterparts, was to find and practise a cooperative mode of transatlantic international politics that was to allow them to avoid returning to the pathologies of 1919 and the inter-war period - and to forge a more sustainable EuroAtlantic peace order. Undoubtedly, they embarked on this endeavour under the conditions of an escalating Cold-War confrontation with the Soviet Union. They also seized on the "Soviet threat" to push forward and accelerate transatlantic integration processes. This, in turn, accentuated and deepened inner-European divisions that could ultimately only be overcome, or so it seemed, after 1989. Their wider concerns, which reached back to the cataclysms of the First World War and the Great Depression, and all the upheaval and disorder they had caused, transcended the context of the Cold War.

The key American Atlanticists of the 1940s and 1950s were firmly resolved not to regress to a new version of post-World War I aloofness and isolationism, which, in their eyes, had contributed to the rise of National Socialism and the undermining of the international order in the 1930s. On these premises, Dean Acheson, Kennan and other protagonists of the Truman administration would ensure a broad basis of bipartisan domestic support, and Euro-Atlantic legitimacy, for unprecedented commitments to (West) European security. This time the goal was to contain what they saw and depicted as an actual communist threat. They would play a leading part in establishing a specific regional alliance, as well as a system of collective security, in the North Atlantic sphere (Acheson 1948; 1969; Kennan 1967). 
A further cardinal lesson derived from what George Kennan, a key architect of America's new European policy, and head of the State Department's Policy Planning Staff, came to see as the failure to accommodate the defeated power of Germany in the original Versailles system that emerged after World War I - and to stabilise the democratic order of the Weimar Republic (Kennan 1944, 1948). This time - following a total war of a different character, and having insisted on a total defeat and "unconditional surrender" of Nazi Germany - US policymakers came to develop distinctly more comprehensive conceptions and policies that addressed three crucial dimensions: the encouragement of Western European efforts to advance towards supranational integration, both to avoid a revival of antagonistic nationalisms and to make West Germany's revitalisation "safe" for its Western neighbours; the comparatively swift integration of what became West Germany into a new (West) European and transatlantic order, under the security umbrella provided by the American nuclear superpower; and, within this wider international framework, the policies of the Truman administration and the activities of US foundations and non-governmental associations, probably provided the most important external stimulus for the inner reform and democratisation of what became the Federal Republic. All of this provided for a "double containment" of Germany and Soviet influence. It also went, however, far beyond this purpose.

\section{West European integration, Atlantic security, and the cardinal German problem}

A crucial element of emerging American conceptions on post-war order was the promotion of some form of (West) European supranational integration within the wider context of the desired transatlantic system. While there were different approaches - some emphasising more economically-oriented and functionalist "integration" others a more aspirational push for political and economic "unification" and a higher degree of independence - the main impulse was to foster an unprecedented degree of European - eventually Western European - unity. In this aspect, new approaches were informed by the attempt to draw lessons from the perceived inadequacies of peacemaking in 1919 and the developments that led to the Second World War. As Kennan initially argued, what had to be prevented was not so much an expansion of Soviet power, but a revival of antagonistic nationalisms; Europe's political and economic reconstruction required above all a secure and sustainable framework. It also required supranational European - and transatlantic - approaches to common economic and political problems (Kennan to Acheson, 23 May 1947, FRUS 1947, III, 225; Kennan 1967, 337). This was a rationale that Secretary of State George Marshall and his successor Acheson fully espoused. The Marshall Plan would be designed to foster and encourage such approaches. Not least, it led to the founding of the Organisation of European Economic Cooperation (OEEC) - an important preliminary step towards the European Economic Community and eventually the European Community itself. 
The other main reason for further American engagement in European integration was undoubtedly that it came to be viewed by American decision-makers - and their Western European counterparts - as a strategy of "order-building" that was imperative to address not only the Soviet threat but also one systemic challenge that ultimately had not been met after World War I: the problem of German power and potential renewed German domination. In short, new ways had to be found and were found, to integrate and "civilise" the defeated power in the nascent post-war order. Policy planners in Washington proposed a wide range of concepts whose common core purpose was to unify (Western) Europe - to such an extent that Germany, and eventually West Germany, could be firmly anchored to it without dominating it. It soon became clear, however, that a transatlantic system of economic linkages and security was required to achieve this. At the same time, the Truman administration responded to British and French interests in tying the United States to Europe - to guard against the Soviet threat, yet also to make Western Germany's revitalisation compatible with their security needs. It was critical not to repeat the scenario of Versailles and the 1920s. At that moment in time, no specific and binding US security commitments could be obtained, which had made efforts to accommodate a republican Germany and to promote an understanding between Germany and France, exceedingly difficult and ultimately impossible.

On the one hand, and by relying on the instrumentalities of the Marshall Plan, American policymakers thus fostered cooperative ties and encouraged "revolutionary" supranational concepts and agreements in Western Europe. Notably, the aspirational integrationist approach advanced by Jean Monnet and, concretely, the Schuman Plan of 1950, which called for the integration of the European coal-and-steel sector and eventually gave rise to the European Coal and Steel Community, thus paving the way for Franco-German reconciliation in the context of Western Europe's progressive integration. On the other hand, and at least as significantly, Dean Acheson and other crucial members of the Truman administration in 1948-49 took the unprecedented step of making - and domestically legitimising - long-term commitments to (Western) European security through the North Atlantic Alliance. Having subsequently encouraged the French project of a European Defence Community, they were instrumental in fostering - after its failure - the swift inclusion of West Germany into the transatlantic alliance, which would be formalised by 1955. They would thus play a leading role in creating and consolidating - not unilaterally, but in cooperation and consultation with Western European and German decision-makers - a new and integrative security system that firmly bound the United States to long-term hegemonic responsibilities in Europe, where it would act as a hegemonic primus inter pares. The NATO system provided an essential security framework for the fledgling Atlantic order as well as West Germany's international integration. It would face numerous challenges and criticisms, but it essentially proved remarkably cohesive, durable and overall legitimate throughout the Cold War - and beyond it.

All of these reorientations, and the transformative developments to which they gave rise, were of course significantly influenced by the distinct dynamics of the escalating Cold War confrontation with the Soviet Union. Essentially, however, and in some ways more profoundly, they can be 
characterised, not least, as attempts to find new ways to deal with the longue durée consequences of the Great War, the $20^{\text {th }}$ century's “original catastrophe." This also applies to a further dimension of American aspirations after 1945. For parallel - yet within this wider inter- and transnational framework - the key decision-makers and policy planners of the Truman administration - and a multi-layered network of official and unofficial actors, associations, and foundations, notably the Ford Foundation - came to transform America's role in post-war Germany in the late 1940s and early 1950s. From the position of an occupying power, which originally pursued strict policies of control and "denazification" under the Potsdam agreement of August 1945, it became an essential senior partner in the context of the Cold War. This transformation of course also deepened the division of post-war Germany and Europe.

Official and private US actors pursued an unprecedentedly ambitious "programme" - a broad range of policies and initiatives whose underlying objective was to "civilise," democratise and economically revitalise the former enemy. This was animated by the idea of tying the newly founded Federal Republic to an emerging Western European, yet also a wider Atlantic community, and of (re)integrating it in a common "Western civilisation." Arguably, US efforts exerted the most significant outside influence on the emergence of a stable and ever more internationally integrated West German state. Important impulses were provided through governmental initiatives and programmes, particularly in the 1950s, the era of US High Commissioner John McCloy. American efforts reached beyond this and centred on the creation of what could be called transnational structures of, and conduits for, American-style liberalisation, democratisation and the spread of American "culture and civilisation."

A particularly striking example of this were the energetic efforts of the most influential American foundation, the Ford Foundation, and notably Shepard Stone, who came to direct the foundation's International Affairs program, to promote an "Americanisation" of the West German state and civil society. Stone strove to "sell" the US model and to win West German "hearts and minds" for American "civilisation," inter alia - as Berghahn (2001) has shown - by building up extensive networks that linked the US, German and Western European politicians, intellectuals, and businessmen.

The remarkable success of US democratisation efforts depended, to a considerable extent, on the resilience and revival of liberal-democratic traditions, and on political leaders whose formative experiences had been made during the Weimar era, and parties that could build on long, though disrupted traditions - particularly the Social Democrats and the Christian Democrats, who revived and reformed the legacy of the Catholic "Centre" party (Jackson 2006; Jarausch 2006). West Germany, of course, remained a "semi-sovereign" state during the Cold War, especially when it came to its international policies. But the prevailing American rationale of giving considerable leeway to, and in fact encouraging, "self-determined" democratisation "on German terms" was also critical and had an overall constructive impact. Characteristically, German representatives were granted considerable independence in drafting the Federal Republic's Constitution. A similar verdict can be passed on American approaches to Germany's economic revitalisation and reform. 
Ludwig Erhard and others could develop what became the underpinnings of the West German model of a social market economy - which was distinct from American-style liberal capitalism, but overall integrated to the US-led economic and financial system for the "free world" within the parameters that Bretton Woods and the Marshall Plan had set.

More importantly, American policies were instrumental in buttressing Konrad Adenauer's policy of "tying (West) Germany to the West" of prioritising West Germany's political, economic, but also military and "civilisational" integration within a Western system, not only as a key ally in the Cold War. Adenauer's course combined European and Atlanticist elements, and it came to prevail over alternative orientations after 1945, such as that towards a "neutral" united Germany advocated by the Social Democratic leader Kurt Schumacher.

\section{A somewhat legitimate "Atlantic Community" - and its civilisational underpinnings}

On a deeper level, and more generally, the new Atlantic peace order thus came to be buttressed by distinct ideas and ideologies of civilisation. In short, from the late 1940s, leading policy - and decision-makers, as well as experts and technocrats and broader elites on both sides of the Atlantic, came to espouse the notion of an emerging "Atlantic community" that was not only based on an interdependence of security and economic interests, but on core elements of a common Western "civilisation" - and a common democratic culture of government and society. This notion would remain contested in many ways, not least by those intellectual and social forces that remained deeply suspicious of what they saw as a detrimental "Americanisation" of European civilisation; but it would gain a hold beyond mere political rhetoric, influencing collective assumptions and mentalities beyond the inner circles of policy planning and decision-making. The idea of an "Atlantic community" of states that espoused American-style Progressive democracy had first been formulated by the publicist Walter Lippmann in 1917, in an article entitled “The Defense of the Atlantic World”, (Lippmann 1917).

Many "Atlanticist" experts in the State Department came to promote the vision of an even more ambitious institutionalised Atlantic "union" between the United States and the democratic states of Western Europe. However, this notion was not espoused by leading policymakers of the Truman administration, who continued to favour a less aspirational "community" constructed around the institutionalised relations of the North Atlantic Alliance and the network of linkages established by the European Recovery Program. In their conception, which Acheson put forward with particular vigour, the United States was cast in the role of a hegemonic patron and protector of this community - and Western civilisation as a whole. They also sought to legitimise unprecedented US commitments to this end by appealing to common values and cultural roots. While some American officials and intellectuals would see it as the nucleus of a "liberal" order for the world - on "Western" terms - the order of the "Atlantic community" was thus based on specific civilisational premises and preconditions. 
The comparatively high degree of legitimacy and durability that the emerging transatlantic system would enjoy were not only or mainly due to such civilisational factors. To a significant extent, it also derived from how the order's hegemon acted in the sphere of international politics and economics (though this was undoubtedly influenced by notions of a common civilisation). Essentially, it stemmed from the fact that those who represented the pre-eminent American power did not impose their concepts and terms, but instead fostered a new transnational consensus on political, strategic and economic ground-rules - which, by and large, they came to act in ways that accorded with the exercise of a rather benign liberal hegemony. On these premises, US decision-makers came to pursue multilateralism and to cooperate with major Western European policymakers of the post-war period, figures like the "Atlanticists and Europeanists" Bevin, Monnet, Schuman, Adenauer or Alcide de Gasperi. Similar processes gained momentum across a broader spectrum of inter-elite cooperation across the Atlantic, both official and unofficial. Furthermore, US administrations maintained their support for concrete efforts to spur supranational integration on which Western Europe's post-war leaders embarked, buoyed by a new groundswell of both national and transnational popular support for such aspirations.

In essence, therefore, the Atlantic system was not characterised by policy-and decision-making at an imperial "centre," but by a new kind of systemic architecture whose main pillars were political, security and financial-cum-economic institutions - chiefly the North Atlantic Alliance and eventually the Organisation for Economic Co-operation and Development (OECD) - that functioned as mechanisms for continual cooperation, political consultation, participation and consensus-building. These institutions allowed European elites to have a voice in decision-making processes. Over time, this helped to create a system of remarkably sustainable political relationships and practices, undergirded by common understandings and mutually accepted ground-rules on which the order rested. This gave rise to networks of official and unofficial actors that became familiar with "transatlantic" policy - and decision-making. This notably characterised the formative phase, roughly the period between the late 1940 s and the early 1960 s.

This is not to belittle either the challenges the transatlantic order would face or the forcefulness of specific opposition to or in some quarters deep-seated resentment of American military predominance and American "cultural imperialism," notably but not only in France, Italy, and West Germany. Both would grow in the 1960s and thereafter, provoked in part by both actual and perceived US high-handedness, yet also by the superpower's conduct in other parts of the world during the global Cold War. As will be seen, the Johnson administration's escalation of the war in Vietnam, closely connected with the attempt to expand "American order" in the so-called "Third World," marked a watershed in this respect. In the early 1980s, a new highpoint would be reached when opposition to Reagan's assertive expansion and modernisation of the American nuclear arsenal, and his ideological offensive to prevail over the "Evil Empire," contributed to mobilising a wide-ranging transnational peace and anti-nuclear movement in Western Europe.

Unsurprisingly, challenges also resulted from what lay in the logic of the original American aspirations of the late 1940s: a process of emancipation of America's European "partners," which, to a greater or lesser, degree led them to pursue their own priorities, as well as to greater independence 
from the United States. A striking example of this would be de Gaulle's aspiration to make France the pre-eminent power in a "Europe of Fatherlands" and European path. A later example would be the German pursuit of Ostpolitik under Willy Brandt and his successor Helmut Schmidt, though both would also reaffirm the Federal Republic's overriding commitment to the "Western system." In the wider historical picture, however, the character and longevity of the US-led transatlantic system of the Cold War can be described as "exceptional;" and so does the degree of wider acceptance and democratically expressed public support for, or at least acquiescence with, the American role in Europe and the "Atlantic community."

\section{A different "Pax Americana" for East Asia?}

Indeed, America's role in the creation of the Cold War's Atlantic system was and remained distinctive in many ways. In the other region they came to view as strategically vital in the aftermath of World War II - East Asia - US decision-makers pursued qualitatively different and more hierarchical conceptions of order. They did so both in defining the United States' hegemonic role and in trying to come to terms with the adverse conditions for approaching anything resembling supranational "integration" in this region, particularly in relations between Japan and the objects of previous Japanese ambitions to create an Asian-Pacific "Co-Prosperity Sphere." Essentially, they came to create a system of "bilateral" relationships and security pacts with clearly less than equal partners. Its nucleus was the so-called "San Francisco system," established through the US-Japanese Peace Treaty and the Security Treaty of 1951. Subsequently, it would also come to include South Korea, Taiwan, and Southeast Asian states. Within this system, and in each partnership, the United States acted as the dominant power. Unquestionably, the more imperious conduct of US decision-makers and wider elites was also influenced by the underlying assumption that there were no grounds for constructing a kind of trans-Pacific civilisational community akin to the "Atlantic community," which in turn were coloured by notions of racial hierarchy and distinctions (Cohen 2002, Katzenstein 2005). In short, American aspirations to lay the groundwork for a "new order" in East Asia and the Pacific after 1945 changed substantially - first, after the so-called "loss of China" to communism, following Mao's victory in the Chinese Civil War and the Chinese Revolution of 1949; later, under the impact of the Korean War and the escalation of a distinctly confrontational East Asian Cold War. All of this especially affected US aspirations to redefine post-war relations with Japan. In the early stages, under the occupation regime led by General Douglas MacArthur, as Supreme Commander of the Allied Powers, an ambitious New Deal-style programme for Japan's post-war rehabilitation had been launched - which had been "embraced" by Japanese elites and the broader population to a remarkable extent (Dower 1999).

As is well-known, the original American agenda included far-reaching demilitarisation measures, as well as initiatives to promote decartelisation and economic and agricultural reforms without imposing US-style laissez-faire capitalism. Notably, these led to the break-up of big 
Japanese industrial conglomerates and ended the dominance of a small number of property-holding families. Integral to the early American approach, however, was an aspirational programme of democratisation - in fact, an expansion of the "Wilsonian mission," the attempt to initiate far-reaching political reforms and a long-term process of "democracy-building" in Japan, notably the promotion of a pluralistic party system that also included communist parties.

All this was "supervised" by US officials and experts. Japan's new post-war constitution, under which the emperor was made a constitutional monarch within a democratic polity, would first be drafted by a Japanese committee, but then be finalised by MacArthur and American legal experts. The American protagonists were not oblivious to the previous history of liberal constitutional government in Japan in the 1920s. However, they relied distinctly less on it than in the case of Germany. There were also aspirations to further not only a political, but also an economic and cultural "Americanisation" of Japan. Despite that, again in contrast to the German case, they did not go hand in hand with the idea, or ideological impetus, to integrate the former enemy in a "community" of like-minded "civilisations."

Once the onset of the East-Asian Cold War - and the "hot war" in Korea - altered the geopolitical playing-field, American priorities changed. In short, the main objective became to make Japan into the United States' key ally, and junior partner, in the system of bilateral pacts it created in East Asia to contain Soviet influence and Communist China. Both Secretary of State Acheson and Kennan saw Japan's economic revitalisation and the forging of close alliance ties as key concerns in efforts to contain communism in the Far East. Japan's further progressive democratisation became a secondary concern (Kennan 1967; Acheson 1969). These underlying American rationales left an imprint on the US-Japanese Security Treaty of 1951, under which the United States essentially turned into Japan's hegemonic protector - while Japan, under the strict limitations imposed by its post-war constitution, provided logistical and financial support and subsequently established "self-defence forces." A key ally for US officials throughout this process was Shigeru Yoshida who, as head of the newly formed Liberal party and five-time prime minister between 1946 and 1954, became the pre-eminent Japanese decision-maker in the post-war period. What became known as the Yoshida doctrine, his approach to Japan's post-war recovery, hinged on a strategic bargain with the United States: Japan would concentrate its policies and resources on economic recovery - under the protection afforded by the American guarantees; in return, Japan would be closely aligned with US Cold War policies and strategic interests in the sphere of regional security and international politics in East Asia and the Pacific.

It was on these premises, and around the security pact with Japan, that the Truman and Eisenhower administrations took charge in forging a succession of bilateral security agreements with East - and eventually also Southeast-Asian states, beginning with the Mutual Defence Treaties with South Korea (in 1953) and Taiwan (1954). Unmistakably, their overriding purpose was the containment of communist influence, both in the domestic and in the international sphere. At the same time, a particular emphasis was placed on fostering economic growth in these states and, crucially, on integrating them into the US-led liberal economic order of the "free world," which also meant far-reaching access to the American market. 
In this system of separate alliances, American decision-makers accepted a certain measure of consultation with Japanese, South Korean, Taiwanese and other partners. They also had to countenance the development of different - and effective - forms of state-guided capitalism, particularly in Japan, which were far removed from American free-market orthodoxies. However, they tended to make the key strategic decisions. Overall, the United States remained the preponderant and not often domineering "patron" in each of the bilateral relationships. What emerged could be called both a more hierarchical and restricted "Pax Americana;" what did not emerge was a regional system of order on a par with the transatlantic peace order outlined above.

\section{Global challenges, maxims of "world leadership" and neo-imperial temptations}

The critical policymakers of the Truman administration had originally sought to pursue a global approach to the international order that was not necessarily premised on the notion that entirely different rules and standards had to be established for Europe, East Asia and what became known as the "Third World." But they subsequently responded to the pressures of the Cold War in ways that were inconsistent with the maxims of "world leadership" they had defined. The same would essentially apply to their successors throughout the Cold War era (Petersen et al. 1977).

The dilemma US strategists confronted or perceived, was that to create the conditions for the global modernisation and reform processes they sought to promote in the core period of decolonisation, they first had to prevent, by all means necessary, Soviet-induced changes in the opposite direction. This motivated numerous American interventions to "create" and control political and economic "order" outside the "Western world" - which in one influential interpretation were instrumental in creating the "Third World" itself (Westad 2005). The interest to ensure access to strategic resources and the interests of client regimes had an impact as well. More generally, a distinct double standard came to characterise global strategies of containment under Truman and even more so under Eisenhower and his successors. It was based on revived hierarchical and often neo-imperial assumptions. This led to a growing discrepancy between the professed principles of the Truman doctrine of 1947, notably the respect for "self-determination," and the overriding strategic "necessities" of the Cold War. All too often, such necessities were interpreted as mandating the support of authoritarian regimes and oligarchic elites loyal to the United States, especially in Latin America - yet eventually also in Africa, the Middle East, and Southeast Asia - to combat communist "subversion."

\section{No Pan-American "Pax Americana"}

This indeed held true in the Western Hemisphere, where, historically, the notion of a "Pax Americana" and a special hegemonic role of the United States had first emerged - yet, where its 
elites had also long accorded themselves quasi-imperial prerogatives of intervention, control, and the pursuit of economic interests under an ever more expansively defined Monroe Doctrine. After World War II, the Truman administration originally aimed to promote democratic reform and development on the premises of Roosevelt's "Good Neighbor" Policy. In this spirit, and based on the UN Charter, it concluded the Rio Pact of 1947, a mutual and collective defence treaty between the US and the nations of Latin America. There would be no Pan-American Marshall Plan. What followed instead were years of both overt and covert US interventionism and support for authoritarian regimes under the late Truman and the Eisenhower administrations, following the main Cold War rationale of suppressing communist infiltration by all available means, with the help of all available allies or client regimes.

The Kennedy administration's "Alliance for Progress," launched at the Punta del Este Meeting of 1961 and with the Charter and "Declaration to the Peoples of America," was intended to mark a new beginning. Its underlying aim was to promote democratisation and political reform in Latin American through economic reform and the promotion of "development." Key objectives included raising Latin American per capita income: 2.5\% per year; social reform, especially land reform; diversification of trade; industrial and other economic development; and education. A total of roughly \$20 billion was to be channelled to Latin American countries over a period of 10 years. The chief architect of the initiative, the economist Walt Rostow, emphasised the primacy of economic development and applied to Latin America his confident conception of kick-starting an economic "take-off" period. This would also engender a transformation of the political landscape across the region, paving the way for prosperous democratic regimes.

Nevertheless, the "Alliance for Progress" agenda confronted substantial problems that could not be managed, let alone overcome. In short, problems stemming from opposition to land reform and, especially, the attitudes of Latin American elites, who sought to bolster their hold on power and resources rather than liberal reform. By the mid-1960s, the general thrust of US policies reverted to prioritising economic growth, "order," and stability over the support for democratic reforms - in what became a decade marked by the rise of military dictatorships across central and South America. Washington thus came to support the military regimes that gained power after coups in Brazil (1964) and Argentina (1966), the Somoza dictatorship in Nicaragua and later, and as notoriously, the Pinochet regime in Chile (Brands 2012; Smith 2007).

\section{The frustrated aspirations to globalise the "American Peace" in the 1960s}

The transformative decade of the 1960s saw an intensification of aspirations to develop global designs for an "American peace" and American-style "order-building" and modernisation - in an effort both to build on and to expand what had been achieved in post-World War II Western Europe (Ekbladh 2009). This decade marked a watershed insofar as such aspirations, and America's post-war hegemony reached distinct limits. It was a period when the attraction and legitimacy 
of US hegemony and the American model of liberal-capitalist democracy were for the first time challenged in a truly global context, foreshadowing debates of the early $21^{\text {st }}$ century. In this wider context, a particularly significant case of US "neo-imperial overreach" can be illuminated by focusing on the Johnson administration's ambition to foster a global "New Deal," and thus extend America's liberal hegemony, particularly in the "Third World." This ambition came to centre on the initiative to develop a "Marshall Plan" for Southeast Asia, and it would founder in Vietnam.

Essentially, Kennedy's successor Lyndon Johnson sought to improve the position of the United States in the global systemic competition with the Soviet Union by both renewing and expanding earlier conceptions of an "American peace" for the world. However, Johnson's policies would fail. In fact, they came to provoke unprecedentedly widespread transnational resistance, and would have grave repercussions on America's credibility as a progressive hegemon and "tutelage" power. Essentially, this can be attributed to the fact that his bid to impose modernisation schemes "and" militarily defeat communist counter-forces in Vietnam led the United States to behave in the manner of a neo-imperialist power.

One cardinal challenge that the Johnson administration faced was a highly problematic global legacy that the earlier $20^{\text {th }}$ century and, on a broader perspective, the era of globalising $19^{\text {th }}$-century imperialism had left behind. In short, the president and his advisers had to come to grips with a particularly conflict-ridden phase in the long-term process of decolonisation. Against this background, they had to search for more effective ways to pursue American-style modernisation policies in parts of the world where nationalist movements had shaken off colonial rule and founded as yet highly fragile independent states (or were keen to do so). While America's confrontation with the Soviet Union and other "polycentric" communist forces was escalating, the crucial challenge was to avoid the pursuit of neo-imperial policies in those countries in which the Cold War antagonism played out and intensified local conflicts - above all, Vietnam. In 1950, the influential strategist Paul Nitze had warned that in "a shrinking world" the "absence of order among nations is becoming less and less tolerable." In his opinion, US policy was thus called upon to go beyond a policy that focused on containing the Soviet Union. It was meant to pursue the primary objective to "bring about order and justice by means consistent with the principles of freedom and democracy" (Foreign Relations of the United States 1977, 241). The manner in which the Johnson administration aspired to do so and to exercise "world leadership" in Vietnam and Southeast Asia would produce manifold unintended and eventually devastating consequences.

Having inherited Kennedy's original commitments in Vietnam, Johnson came to champion the idea of a Marshall Plan for Vietnam and Southeast Asia. He deemed it imperative to prevent a communist takeover in Saigon. More importantly, though, his "vision" for Vietnam and the wider region was part and parcel of his aspiration to expand his "Great Society" reformist zeal and New Deal-style modernisation to the developing world - and to wage a global "war on poverty." Johnson eventually seized on maxims at the heart of the modernisation theories that the aforementioned MIT economist Rostow had developed. Rostow had exerted a crucial influence on the Kennedy administration's approach to the "Third World" (Rostow 1972). He had argued that America's 
successful promotion of Western Europe's reconstruction after 1945 set a formative precedent. Based on this premise, the president proposed an aspirational strategy that was to bolster massive economic development in Southeast Asia, arguing that this would place the most effective checks on the expansion of communism. He thus put forward what amounted to an adapted Marshall Plan for the region, arguing that it would notably allow Vietnam to enter a "take-off" period of rapid industrial growth and agricultural surpluses. On these premises, the centrepiece of the Johnson administration's regional modernisation strategy for Southeast Asia became the Mekong River Project. It centred on the construction of a network of dams devised to include not only Vietnam, but also Cambodia, Laos and Thailand. In many ways, this scheme, promoted by the Ford Foundation, was modelled on the centrepiece of New Deal public works programmes, the Tennessee Valley Authority.

Facing the urgent challenge of advancing a "constructive policy" for Vietnam and wider Southeast Asia, Johnson also relied on the expertise of the US Agency for International Development (USAID), which had been created in 1961 as an independent body to oversee America's official development policies. Like Kennedy, Johnson seized on ideas spawned by a newly relevant liberal development community - a community characterised by a network of relations between government agencies, non-governmental activists and international organisations, notably the agencies of the UN Economic and Social Council. What is most striking about the American pacification and modernisation strategies that came to prevail in the 1960s was the degree of technocratic planning and the absoluteness of the claims that informed them - above all, the claim that the concepts and methods proposed for attaining US peace objectives were based on advances in social science and, notably, economic theory; that they offered allegedly objective standards and guidelines that could be applied on a global scale, to both developed and developing countries, with ever less concern for "facts on the ground" and specific historical preconditions (Latham 2000, Ekbladh 2009).

It should be noted, though, that ever since the First World War, the advancement of US grand designs for the global order had also provoked many contentious debates. In the 1950s, one influential critical voice, the aforementioned theologian Reinhold Niebuhr, had made out "a deep layer of Messianic consciousness" in American culture, which was also "strongly influenced by both scientific concepts and technocratic illusions" (Niebuhr 2008, 74-5). He beseeched US policymakers not to use their immense "political power" to develop "[s]chemes for the management of human nature" (Niebuhr 2008, 74-5) that denied "the dignity of man" by their neglect of the chief source of man's dignity, namely, his essential freedom and capacity for self-determination (Niebuhr 2008). Controversies between "liberals," "technocrats" and "realists" raged inside and outside US policymaking circles throughout the 1960s and would not stop with the end of the Cold War.

Johnson himself would forge ahead with his plans to promote ambitious New Deal-style initiatives for Southeast Asia. His administration would not only support existing "major programs of development" but also "[w]ider and bolder programs" from "Asian leaders" to prepare the ground for a future when "the people and governments of all South East Asia" would "need not military support" but "only economic and social cooperation for progress in peace" (Johnson 1965; 1966; 
1971). The means his administration used to reach its goals soon undermined Johnson's hopes. In essence, it came to pursue the Vietnam conflict as a unilateral war, which, instead of reforming South Vietnam, only extended an inherently illegitimate, and brittle, American domination. The authoritarian and corrupt regimes the United States came to back in its efforts to contain communist subversion, from Ky's government all the way to General "Big Minh," never acquired a modicum of popular support and continued to be seen as "puppets" of the United States.

Overall, the hallmark of the Johnson administration's approach to Vietnam was and remained a distinctly hierarchical conception of how to "create" order in countries and societies outside the "Western world." The Vietnam fiasco underscored the limits of US attempts to impose American "remedies" on the developing world, and to crudely apply concepts that had been developed either for advancing domestic reforms in the United States, or for stabilising the very different political and economic constellations of post-war Europe and Japan. At the same time, America's "imperialistic war" not only stirred up unprecedented levels of domestic protest and transnational opposition. It also damaged the authority of US leadership in the Western alliance system and among America's East Asian allies, not to mention the appeal of Johnson's "war on poverty" and US-style "modernisation" in the developing world. All this had a profoundly corrosive longterm effect on the legitimacy of American aspirations for "world leadership," and a global "Pax Americana" for the remainder of the Cold War - and beyond (Suri 2003).

\section{Conclusion}

Starting with Wilson's quest to "make the world safe for democracy" all prevalent aspirations for an American international order were based on essentially progressive premises. Central among them was the premise that the United States could offer not only Europe and East Asia, but also the wider, eventually post-colonial world a transformative approach to more durable peace, stability, and prosperity: towards a "new world order" of collective security, liberal democracy, and capitalism, which - according to a prevalent, yet also contested set of assumptions - was to be based on specifically American, yet globally applicable rules and principles.

Both conscious pursuits of an "American peace" and the wider influence of American power, ideas and ideologies, have had an unprecedented international and transnational impact in the $20^{\text {th }}$ century. Whether positive or negative, they came to affect national, regional and supranational transformation processes, particularly those that gained momentum in Western Europe and across the Atlantic after 1945. Eventually, they also affected the globalisation processes to which they gave a fresh impetus in the 1970s and 1980s and which have accelerated since the end of the Cold War. However, concrete ambitions to expand a "Pax Americana" only contributed to the creation of more legitimate systems of order if their protagonists did not act as neo-imperial crusaders who forced their "visions" of peace and order on others, but rather as a "primi inter pares," who played a leading role in cooperative, essentially transnational efforts with the representatives of other 
states and societies, to forge common and mutually acceptable principles and rules, institutions and mechanisms of order.

In many ways, this only came to characterise the American role in the formation and consolidation of the $20^{\text {th }}$ century's distinctive transatlantic peace order. It applied less, or only selectively, to US conduct in post-World War II East Asia. By and large, it did not apply to the United States' relations with the other regions of the world, nor did it apply on a global scale. Ultimately, but only after the denouement of the Cold War, the Atlantic system of order would be extended from its Western nucleus to the states and societies of Eastern Europe, and a wider European sphere, overcoming the continent's long-standing divisions. The developments that cumulated in the transformative changes between 1989 and 1991, the peaceful revolutions in Eastern Europe and the subsequent collapse of the Soviet Union, had been influenced by US policies. It also unfolded in many respects beyond their reach. Grander expectations that arose after 1991 - hopes that the remaining superpower would be able to seize on a unipolar moment in history to build an "American world order" for the $21^{\text {st }}$ century - proved premature. They would not be fulfilled, which not least had to do with the multiple legacies of American "Cold War imperialism” - and renewed imperial temptations.

\section{References}

"Acheson speech," Dean Acheson Papers; Philadelphia: Truman Presidential Library, Independence, Missouri, box 4, 10 March 1948. Kennan memorandum, March 1944, Kennan Papers, box 163;

Kennan, G. F. “Kennan memorandum PPS/23, 24 February 1948”. Policy Planning Staff (1948), 110-13.

Kennan, G. F. F. “Kennan to Acheson, 23 May 1947.” Foreign Relations of the United States, 225. Washington, D.C.: [USA]. vol. 3.

Acheson, D. Present at the Creation: My Years in the State Department. New York: Norton, 1969. Berghahn, V. R. America and the Intellectual Cold Wars in Europe. Princeton, N.J.: Princeton University Press, 2001.

Borgwardt, E. A New Deal for the World: America's Vision for Human Rights. Cambridge, MA: Harvard University Press, 2005.

Brands, H. Latin America's Cold War. Cambridge, MA: Harvard University Press, 2012. Clark, I. Hegemony in International Society. Oxford: Oxford University Press, 2011. Cohen, W. C. The Asian American Century. Cambridge, MA: Harvard University Press, 2002. Cohrs, P. O. The Unfinished Peace after World War I: America, Britain and the Stabilisation of Europe, 1919-1932. Cambridge, MA: Cambridge University Press, 2006.

Cohrs, P. O. "Pax Americana." In The Palgrave Dictionary of Transnational History: From the mid-19th century to the present day, edited by A. Iriye, and P-Y. Saunier. London: Palgrave Macmillan, 2009. 
Cohrs, P. O. "No PaxAtlantica for the $20^{\text {th }}$ Century. The Struggle to Found a Transatlantic Order of Peace and Security: A Key Problem of the Re-ordering Processes of 1919.” In Große Erwartungen. 1919 und die Neuordnung der Welt, edited by J. Leonhard. Munich: Schriften des HistorischenKollegs, unpublished.

Cox, M., T. Dunne, and K. Booth, eds. Empires, Systems and States: Great Transformations in International Politics. Cambridge, MA: Cambridge University Press, 2001.

Dower, J. W. Embracing Defeat: Japan in the wake of World War II. New York: Norton, 1999. Ekbladh, D. The Great American Mission: modernization and the construction of an American world order. Princeton, N.J.: Princeton University Pres, 2009.

Foreign Relations of the United States, 1950. Washington, D.C.: United States Government, 1977. v. I.

Petersen, N. H., J. P. Glennon, D. W. Mabon, R. R. Goodwin, and W. Z. Slany, eds. Foreign Relations of the United States 1950, National Security Affairs; Foreign Economic Policy. Washington, D.C.: United States Government Printing Office, 1977. v. 1. Fulbright, W. The Arrogance of Power. New York: Random House, 1966.

Gaddis, J. We Now Know: rethinking Cold War history. Oxford: Clarendon Press, 1997. Hunt, M. H. The American Ascendancy: how the United States gained and wielded global dominance how the United States gained and wielded global dominance. Chapel Hill, N.C.: University of North Carolina Press, 2007.

Ikenberry, G. J. Liberal Order and Imperial Ambition: Essays on American power and international order. Cambridge, MA: Polity Press, 2006.

Ikenberry, G. J. Liberal Leviathan: The origins, crisis, and transformation of the American world ordeI. Princeton, N.J.: Princeton University Press, 2011.

Iriye, A, J. Osterhammel, eds, Global Interdependence: the world after 1945. Cambridge, MA: Harvard University Press, 2014.

Jackson, P. T. Civilizing the enemy: German reconstruction and the invention of the West. Ann Arbor: University of Michigan Press, 2006.

Jackson, P. Beyond the balance of power: France and the politics of national security in the era of the First World War. Cambridge, MA: Cambridge University Press, 2013.

Jarausch, K. H. After Hitler: recivilizing Germans, 1945-1995. Oxford: Oxford University Press, 2006.

Jervis, R. Perception and misperception in international politics. Princeton, N.J.: Princeton University Press, 1976.

Johnson, L. B. Vantage point; perspectives of the Presidency, 1963-1969. New York: Holt, Rinehart and Winston, 1971.

Johnson, L. B. "Peace without Conquest, 7 April 1965," The Public Papers of the Presidents of the United States, 394-9. Washington, D.C.: USA, 1966., vol. I.Katzenstein, P. J. A world of regions: Asia and Europe in the American Imperium. Ithaca, N.Y.: Cornell University Pres, 2005. 
Kennan, G. F. Realities of American foreign policy. Princeton, N.J.: Princeton University Press, 1954.

Kennan, G. F. Memoirs, 1925-1950. Boston: Little, Brown, 1967.

Khong, Y. F. Analogies at war: Korea, Munich, Dien Bien Phu, and the Vietnam decisions of 1965. Princeton, N.J.: Princeton University Press, 1992.

Latham, M. E. Modernization as ideology: American social science and "nation building" in the Kennedy era. Chapel Hill, N.C.: University of North Carolina Pres, 2000.

Lippmann, W. (1917). “The Defense of the Atlantic World.” New Republic, 1917, 59-61.

Lundestad, G. The "empire" and other studies of US foreign policy in a comparative perspective. Oxford: Oxford University Press, 1990.

Lundestad, G. The United States and Western Europe since 1945 : from "empire” by invitation to transatlantic drift. Oxford: Oxford University Press, 2003.

Maier, C. S. Among empires: American ascendancy and its predecessors. Cambridge, MA: Harvard University Press, 2006.

May, E. R. "Lessons" of the past; the use and misuse of history in American foreign policy. New York: Oxford University Press, 1973.

Menzel, U. Die Ordnung der Welt: Imperium oder Hegemonie in der Hierarchie der Staatenwelt. Berlin: Suhrkamp, 2015.

Niebuhr, R. The irony of American history. Chicago: University of Chicago Press, 2008.

O'Brien, P. K., and A. Clesse. Two hegemonies: Britain 1846-1914 and the United States 1941-2001. Aldershot: Ashgate, 2002.

Patel, K. K. The New Deal: a global history. Princeton, N.J.: Princeton University Press, 2016. Rosenman, S., ed. The Public Papers and Addresses of Franklin D. Roosevelt, 1940-1945. New York: Random House, 1941.

Roosevelt, F. “Roosevelt's World Blueprint”, Saturday Evening Post, 10 April 1943, 20-1, 109. Rostow, W. W. The diffusion of power; an essay in recent history. New York: Macmillan, 1972. Schroeder, P. W. 'The Mirage of Empire Versus the Promise of Hegemony,' In Systems,

Stability, and Statecraft, p. 297-306. New York: Palgrave Macmillan, 2004.

Smith, P. H. Talons of the Eagle. Oxford: Oxford University Press, 2007.

Suri, J. Power and protest: global revolution and the rise of détente. Cambridge, MA: Harvard University Press, 2003.

Trachtenberg, M. A Constructed Peace. Princeton, N.J.: Princeton University Press, 1999. Thompson, J. A. A sense of power. the roots of America's global role. Ithaca, N.Y.: Cornell University Press, 2015.

Tooze, A. The deluge: the Great War, America and the remaking of the global order, 1916-1931. London: Penguin Books, 2015.

Westad, O. A. The global Cold War: third world interventions and the making of our times. Cambridge, MA: Cambridge University Press, 2005. 